\title{
IMPLEMENTASI UNDANG-UNDANG NOMOR 1 TAHUN 2013 TERHADAP LEMBAGA KEUANGAN MIKRO SYARIAH YANG BERBADAN HUKUM KOPERASI
}

\author{
Muhammad Amin \\ Universitas Islam Negeri Sunan Kalijaga \\ Email:Amien_alkatiri16@yahoo.co.id \\ Abstract
}

The existence of the 2013 law No. 1 concerning LKM (microfinance institution) affects Sharia LKM (LKMS) whether it is incorporated as a cooperative or limited liability company to adjust their institutional form, operational system, business fields, capital, and other aspects to get business permit from OJK (Financial Services Authority). However, the mandatory consequences of LKMS to get business permit have not run optimally. The interesting thing to discuss is the obedience of Sharia LKM Cooperative in implementing The Law on LKM. This study uses empirical legal approach and makes LKMS Anggrek and BMT Surya as the sample. The study reveals that LKMS Anggrek registered in OJK by changing its statute. Meanwhile, BMT Surya chooses the 2015 Ministry Regulation No. 16 to give legal protection to operational permits and has cooperative as supervisor. The obedience of LKMS Anggrek is in line with normative commitment through legitimation in identification process, and is an effort creating Service City program (bifz an nafs) and economic development (bifz al mal). Whereas, the legal awareness of BMT Surya toward The Law on LKM does not easily make it obey the rule. However, the asset management is an effort toward hifz al mal and the good relation with cooperative as supervisor is an effort toward hifz an nafs.

Eksistensi UU LKM menimbulkan konsekuensi bagi LKM Syariah (LKMS) yang berbadan hukum koperasi maupun perseroan terbatas untuk menyesuaikan bentuk kelembagaan, sistem operasional, bidang usaha, permodalan dan aspek lainnya untuk memperoleh izin usaha dari OJK. Akan tetapi konsekuensi wajibnya LKM Syariah untuk memperoleh izin usaha pada OJK belum berjalan dengan optimal. Hal yang menarik untuk dikaji adalah kepatuhan Koperasi LKM Syariah dalam mengimplementasikan UU LKM. Metode penelitian yang digunakan adalah 
yuridis empiris. Sample yang digunakan adalah LKM Syariah Anggrek dan BMT Surya. Hasilnya adalah Koperasi LKMS Anggrek mendaftar pada OJK dengan perubahan anggaran dasar, sedangkan BTM Surya tidak demikian, melainkan memilih PERMEN No 16 tahun 2015 dalam memberikan payung hukum ijin operasionalnya dan pembinaan berada dibawah dinas koperasi. Kepatuhan Koperasi LKMS Anggrek tidak lepas dari komitmen normatifmelalui legitimasipada tahapan identification, serta upaya pewujudan program "Service City" (bifz an-nafs) dan perkembangan ekonomi, (bifzal-mal). Sedangkan, kesadaran bukum BTM Surya terhadap UU LKM, tidak serta merta membuatnya patuh. Namun, pengeelolaan harta merupakan upaya (bifz al-mal), dan hubungan baik dengan dinas koperasi selaku lembaga pengawas merupakan upaya (bifz an-nafs).

Keywords: microfinance institution, implementation, cooperatively incorporated sharia micro finance institution

\section{Pendahuluan}

Lembaga keuangan mikro syariah (Baitul Maal wat Tamwil) ${ }^{1}$, dan Baitul Tamwil Muhamadiyyah maupun Koperasi Syariah) merupakan suatu lembaga keuangan mikro yang menerapkan konsep syariah dalam operasionalnya. Kehadiran Lembaga Keuangan Mikro Syariah (LKMS) dipersiapkan guna menyerap aspirasi masyarakat muslim di tengah kegelisahan kegiatan ekonomi dengan prinsip riba (bunga), dan juga sekaligus sebagai supporting funding untuk mengembangkan kegiatan pemberdayaan usaha kecil dan menengah. Tidak cukup sampai disitu, LKMS juga dirasakan telah membawa manfaat finansial bagi masyarakat, terutama masyarakat kecil yang tidak sepaham dengan sistem konvensional dan menolak riba.

Lahirnya Undang-Undang Nomor 1 Tahun 2013 tentang Lembaga Keuangan Mikro membawa angin segar dalam perlindungan hukum terhadap lembaga keuangan mikro. Karena adanya keleluasaan bagi lembaga keuangan mikro untuk berbasis syariah maupun konvensional serta berbadan hukum koperasi ataupun perseroan terbatas. ${ }^{2}$ Namun juga menimbulkan konsekuensi bagi lembaga keuangan mikro tidak terkecuali yang berbasis syariah untuk tunduk akan ketentuan-ketentuan yang ada dalam Undang-Undang Nomor 1 Tahun 2013 tentang Lembaga Keuangan Mikro beserta peraturan turunannya.

1 Lembaga alternatif dengan menggabungkan konsep maal dan tamwil dalam satu kegiatan lembaga. Konsep maal yang diterapkannya merupakan ruh kehidupan masyarakat muslim Indonesia dalam hal menghimpun dan menyalurkan dana untuk zakat, infak dan sedekah (ZIS). Sedangkan, konsep tamwil yang diusungnya, bergerak untuk kegiatan menghimpun dan menyalurkan dana masyarakat dan bersifat bisnis (profit motive), lihat Izza Marullah, "Membumikan Konsep Syariah Dalam Ekonomi Berbasis Kerakyatan (Baitul Maal wat Tamwil Sebagai sebuah Solusi)," Jurnal Ekonomi Pembangunan, 2002. h. 195-205.

2 Pasal 5 ayat (1) Undang-Undang Nomor 1 Tahun 2013 tentang Lembaga Keuangan Mikro "Bentuk badan hukum lembaga keuangan mikro adalah koperasi atau perseroan terbatas". 
LKMS yang berbadan hukum koperasi maupun perseroan terbatas harus menyesuaikan bentuk kelembagaan, sistem operasional, bidang usaha, permodalan, dan seluruh aspek terkait dengan ketentuan-ketentuan yang termaktub dalam peraturan perundang-undangan tersebut. Hal ini pulalah yang menjadikan dasar hukum bagi otoritas jasa keuangan dalam melaksanakan tugasnya seputar pengawasan terhadap lembaga keuangan mikro.

Polemik tentang legalitas LKMS yang berbadan hukum koperasi mulai mencuat. Karena secara tidak langsung LKMS yang berbadan hukum koperasi diatur oleh dua regulasi negara. Regulasi pertama ialah Undang-Undang Nomor 1 Tahun 2013 tentang Lembaga Keuangan Mikro dan regulasi kedua ialah Undang-Undang Nomor 25 Tahun 1992 tentang Perkoperasian. ${ }^{3}$ Sehingga pemilihan badan hukum yang digunakan dalam sebuah LKMS akan berdampak pada aturan sampai kepada pengawasan dan pembinaannya. ${ }^{4}$

Amanat Undang-Undang Nomor 1 Tahun 2013 tentang Lembaga Keuangan Mikro terkait konsekuensi wajibnya LKMS untuk memperoleh izin usaha pada otoritas jasa keuangan nampaknya belum berjalan optimal. Faktanya sampai saat ini hanya ada 17 LKMS yang telah mendaftarkan lembaganya kepada otoritas jasa keuangan. ${ }^{5} \mathrm{Hal}$ ini tentu saja memberikan signal kejanggalan, di tengah pertumbuhan LKMS yang sangat pesat.

Nourma Dewi ${ }^{6}$ telah melakukan penelitian mengenai regulasi BMT di Indonesia dalam sistem perekonomian, ia mendapati regulasi BMT begitu banyak, mulai dari Undang-Undang Lembaga Keuangan Mikro, Undang-Undang Pengelolaan Zakat maupun Undang-Undang Perkoperasian. BMT yang memiliki karakteristik khusus dalam pelaksanaannya (komersil dan sosial) menyebabkan banyaknya aturan yang dapat masuk untuk mengaturnya.

3 Pada faktanya peraturan yang ada, menjadi tumpang tindih karena Baitul Maal wat Tamwil yang berbadan hukum koperasi juga mempunyai aturan lain yaitu Undang-Undang Nomor 25 Tahun 1992 Tentang Perkoperasian. Tentu saja seluruh badan hukum koperasi akan tunduk pada UndangUndang tersebut.

4 Apabila koperasi menjadi pilihan badan hukumnya, maka syarat pendiriannya akan menjadi ringan tanpa adanya batasan modal pendirian dan pembinaanya pada kementrian koperasi dan UMKM. Lihat Neni Sri Imaniyati, Aspek-Aspek Hukum BMT (Baitul Maal Wat Tamwil) (Bandung: Citra Aditya Bakti, 2010), h. 102.

5 "Data Lembaga Keuangan Mikro Yang Terdaftar Di Ojk Per 30 September 2017," 30 Januari 2018, http://www.ojk.go.id.

6 Nourma Dewi, "Regulasi Keberadaan Baitul Maal Wat Tamwil (BMT) Dalam Sistem Perekonomian Di Indonesia," Jurnal Serambi Hukum 01 (Juni 2017), h. 96-110. 
Dilanjutkan penelitian oleh Muhammad Muhtarom ${ }^{7}$ yang menyimpulkan adanya ketidakharmonisan peraturan perundang-undangan tentang LKMS yang disebabkan karena inkonsistensi penerapan kerangka-kerangka hukum dalam mengatur LKM dan koperasi syariah yang beraneka ragam coraknya, serta adanya ketidakpatuhan terhadap asas materi muatan pembentukan undangundang sebagaimana diatur dalam Undang-Undang Nomor 12 Tahun 2011 tentang Pembentukan Peraturan Perundang-Undangan.

Selanjutnya Novita Dewi Masyitoh ${ }^{8}$ dengan hasil penelitiannya, BMT dapat berbadan hukum koperasi dan tunduk pada Undang-Undang Perkoperasian dan turunan aturannya. Selain itu, juga dapat berbadan hukum perseroan terbatas dan tunduk pada aturan otoritas jasa keuangan. Dilematika yang terjadi apabila BMT beroperasi dalam lebih dari satu lingkupan kabupaten/kota. Maka sesuai amanat Undang-Undang tersebut, harus bertransformasi menjadi BPR/BPRS. Hal ini selaras dengan hasil karya ilmiah Fadillah Mursid", Undang-Undang Lembaga Keuangan Mikro cenderung mendorong perkembangan BMT ke arah lembaga keuangan seperti halnya perbankan dan menggeser hakikat serta konsep yang diusung oleh BMT.

Disertasi Muhammad Kamal Zubair ${ }^{10}$ menyimpulkan sustainabilitas suatu BMT di Yogyakarta juga sangat dipengaruhi oleh faktor eksternal, baik berupa pengawasan yang baik serta regulasi hukum yang mendukung kelancaran operasional BMT tersebut. Berdasarkan keberagaman penelitian terdahulu, terdapat berbagai aturan yang dapat menunjang operasional dan sustainabilitas LKMS. Hal ini menimbulkan perbedaan dalam penerapan aturan, berdasarkan atas persepsi dari lembaga keuangan mikro konvensional maupun syariah. Sehingga penyusun tertarik meneliti Implementasi Undang-Undang Lembaga Keuangan Mikro pada LKMS yang berbadan hukum koperasi. Undang-Undang Nomor 1 Tahun 2013 tentang Lembaga Keuangan Mikro hadir untuk memberi kejelasan terhadap kelembagaan LKMS akan tetapi Kementrian Koperasi melalui PERMEN KUKM No 16/PER.M.KUKM/IX/2015 berperan serta dalam mengatur KSPPS yang ada di Indonesia. Sehingga bagaimana tahapan

7 Muhammad Muhtarom, "Reformulasi Peraturan Hukum Lembaga Keuangan Mikro Syariah Di Indonesia," PROFETIKA, Jurnal Studi Islam 17 (Juni 2016), h. 90-102.

8 Novita Dewi Masyitoh, "Analisis Normatif Undang-Undang No 1 Tahun 2013 Tentang Lembaga Keuangan Mikro (LKM) Atas Status Badan Hukum Dan Pengawasan Baitul Maal Wat Tamwil (BMT)," CONOMICA: Jurnal Pemikiran dan Penelitian Ekonomi Islam V (Oktober 2014): 17-36.

9 Fadillah Mursid, "Kebijakan Regulasi Baitul Maal Wat Tamwil (BMT) di Indonesia" (Tesis, UIN Sunan Kalijaga, 2017).

10 Muhammad Kamal Zubair, "Sustainabilitas Lembaga Keuangan Mikro Syariah" (Disertasi, UIN Sunan Kalijaga, 2016). 
kepatuhan hukum LKMS yang berbadan hukum koperasi terhadap regulasi yang ada, serta alasan yang melatar belakangi kepatuhannya.

\section{Metode Penelitian}

Jenis penelitian yang dipergunakan dalam penelitian ini adalah penelitian lapangan (field research). Adapun langkah yang dilakukan penyusun dalam mendapatkan data yang dibutuhkan yaitu dengan melihat secara langsung ${ }^{11}$ operasional LKMS yang berbadan hukum koperasi. Penelitian ini dilakukan pada LKMS yang berbadan hukum koperasi, yaitu Koperasi LKMS Anggrek yang beralamatkan Jalan Riau Nomor 12 Kelurahan Kranggan Kecamatan Kranggan Kota Mojokerto dan Baitul Tamwil Muhammadiyah Surya yang beralamatkan Jalan Glagah Sari Nomor 136, Umbulharjo, Yogyakarta. Penelitian ini bersifat deskriptif analitik yaitu penelitian yang bertujuan memberikan gambaran yang jelas mengenai pengaturan LKMS yang berbadan hukum koperasi. Meliputi sikap LKMS yang berbadan hukum koperasi dalam mematuhi Undang-Undang Nomor 1 Tahun 2013 tentang Lembaga Keuangan Mikro, serta poin-poin yang diimpelementasikan sampai kepada maksud dan alasan normatif dari kepatuhan dan ketidakpatuhan tersebut. Adapun pendekatan yang digunakan ialah pendekatan normatif.

Jenis data dimulai dengan data primer yang didapatkan dari hasil wawancara dengan pengurus LKMS yang berbadan hukum Koperasi. Dilanjutkan dengan data sekunder berupa buku ataupun karangan lainnya yang memiliki keterkaitan, penggunaan data sekunder ini untuk memperkuat penemuan data dan melengkapi informasi. Analisis data yang digunakan dalam penelitian ini ialah dengan cara induktif ${ }^{12}$ Tahap akhir dari analisis data ini adalah mengadakan pemeriksaan keabsahan data. Setelah tahap ini, penyusun melakukan tahap penafsiran data dari hasil sementara, berdasarkan kerangka teori yang telah dibangun sebelumnya sekaligus menarik kesimpulan dari hasil penelitian.

\section{Pembahasan}

\section{Implementasi Undang-Undang Nomor 1 Tahun 2013 tentang Lembaga Keuangan Mikro pada LKMS yang Berbadan Hukum Koperasi.}

LKMS merupakan suatu hasil pengembangan modifikasi dari lembaga

11 Iqbal Hasan, Methode Penelitian dan Aplikasinya (Jakarta: Ghalia Indonesia, 2002), h. 11.

12 Induktif yaitu analisa yang berangkat dari pengetahuan yang sifatnya khusus menuju hal yang bersifat umum. Memilih dari aturan yang telah ada untuk diambil beberapa poinnya. Lihat Lukman Hakim, Methodologi Penelitian (Surakarta: UMS Press, 2004), h. 6. 
keuangan mikro. Kegiatan usahanya pun tidak jauh berbeda dengan lembaga keuangan mikro sebagai lembaga yang melayani jasa pengembangan usaha atau pemberdayaan masyarakat melalui pinjaman atau pembiayaan dengan skala mikro. Hanya saja LKMS menerapkan basis syariah dalam sistem operasionalnya serta dapat mengelola dana sosial dari nasabah dan anggotanya. ${ }^{13}$

LKMS yang berbadan hukum koperasi memang beberapa tahun belakangan ini begitu pesat perkembangan pertumbuhannya. ${ }^{14} \mathrm{Hal}$ ini berjalan beriringan dengan meningkatnya kesadaran masyarakat muslim Indonesia untuk menggunakan sistem syariah dalam kegiatan ekonominya, apalagi lingkungan Indonesia mayoritas dihuni masyarakat muslim.

Berangkat dari fenomena pesatnya perkembangan LKMS disertai dengan besarnya animo masyarakat tersebut, membuat aparat pembuat hukum negara mewujudkan adanya regulasi akan keberadaan LKMS. Tentu saja, karena begitu riskannya suatu lembaga keuangan apabila tidak diberikan regulasi yang jelas dan tegas. Fenomena tersebut tidak lepas dari teori kepatuhan hukum yang diungkapkan oleh Robert Biersted. ${ }^{15}$

13100 Koperasi Besar Indonesia 2017 versi majalah Peluang. Peringkat ke-1 diduduki oleh Koperasi Simpan Pinjam (Kospin) Jasa Pekalongan yang memiliki asset hingga lebih dari Rp 7 triliun dan volume usaha mencapai Rp 4,6 triliun. Peringkat ke-2 ditempati ole Koperasi Kredit (Kopdit) Lantang Tipo Sanggau dengan asset Rp 2,6 triliun dan volume usaha Rp 1,8 triliun. Peringkat ke-3 diduduki oleh Kisel Jakarta dengan asset Rp 1,09 triliun dan volume usaha Rp 5,7 triliun. Peringkat ke-4 ditempatiolehKoperasi BMT UGT Sidogiri yang memilikiasetRp 2,2triliundan volume usahaRp 2,05 triliun. Sedangkan, peringkat ke-5 diduduki oleh Kopdit Pancur Kasih Pontianak yang memiliki asset Rp 2,01 triliun dengan volume usaha Rp 1,3 triliun. Kelima koperasi tersebut merupakan lima besar koperasi berdasarkan buku 100 Koperasi Besar Indonesia 2017 karya Irsyad Muchtar yang terbitkan oleh majalah Peluang. Peluncuran buku tersebut dilakukan bersama Menteri Koperasi dan UKM AAGN Puspayoga di Gedung Kemenkopdan UKM, DI Jalan HR Rasuna Said, Jakarta. Mokh Syaiful Bakhri, "BMT UGT Sidogiri Urutan 4 (empat) Koperasi Besar Indonesia," 17 Januari 2018, http://bmtugtsidogiri.co.id/baru/berita-505.html.

14 Perkembangan koperasi syariah sangat baik di Indonesia. Saat ini jumlah unit usaha koperasi mencapai 150.223 unit usaha dan jumlah tersebut 1,5 persennya merupakan koperasi simpan pinjam pembiayaan syariah (KSPPS). Dan tercatat jumlah KSPPS sebanyak 2.253 unit dengan anggota 1,4juta orang. Modal sendiri mencapai Rp 968 Miliar dan modal luar Rp 3,9 triliun dengan volume usaha mencapai Rp 5,2 triliun. Ketika menjadi salah satu pembicara dalam Dialog Tingkat Tinggi dengan Dewan Pengarah Komite Nasional Keuangan Syariah (KNKS) pada Festival Ekonomi dan Keuangan Syariah, Braman Setyo, Deputi Pembiyaan Kementerian Koperasi dan UKM mengatakan saat ini perkembangan koperasi pembiayaan syatiah sangat potensial kinerjanya. Dan saat ini sangat baik, berkualitas dari sisi kesehatan koperasi, SDM dan IT.Nely Merina, "Jumlah Koperasi Syariah di Indonesia Mencapai 150.223,” 17 Januari 2018, https://www.google.com/ amp/goukm.id/jumlah-koperasi-syariah-di indonesia mencapai-150-223/amp/.

15 Proses kepatuhan seseorang terhadap hukum mungkin terjadi karena didasari beberapa faktor yaitu (1) Indoctrination yaitu sebab mengapa warga masyarakat mematuhi kaedahkaedah karena diindoktrinir untuk berbuat demikian. (2) Habituation, proses sosialisasi 
Hal di atas merupakan interprestasi dari struktur hukum, maksudnya aparatur dan sistem penegak hukum menjembatani sebuah sistem hukum yang baik. Selain itu, juga merupakan latar belakang lahirnya Undang-Undang Nomor 1 Tahun 2013 tentang Lembaga Keuangan Mikro.

Kelahiran Undang-Undang Nomor 1 Tahun 2013 tentang Lembaga Keuangan Mikro memberikan regulasi baru kepada LKMS yang berbadan hukum koperasi. Hal ini terlampir dalam Pasal 39 ayat $1{ }^{16}$ yang menyatakan Baitul Maal wat Tamwil dan Baitul Tamwil Muhammadiyah merupakan cakupan dari lembaga keuangan mikro, dan Pasal 39 ayat $2^{17}$ menyatakan kewajiban LKMS untuk memperoleh izin usaha dari otoritas jasa keuangan. Padahal regulasi sebelumnya, LKMS yang berbadan hukum koperasi diharuskan patuh pada Undang-Undang Nomor 25 Tahun 1992 tentang Perkoperasian.

Pada kedua aturan tersebut, tampak dualisme regulasi terhadap LKMS yang berbadan hukum koperasi. Hal itu dapat ditemui pada Undang-Undang Nomor 1 Tahun 2013 tentang Lembaga Keuangan Mikro dan Undang-Undang Nomor 25 Tahun 1992 tentang Perkoperasiandan peraturan turunannya yaitu Peraturan Menteri Koperasi dan Usaha Kecil dan Menengah Republik Indonesia Nomor 16/PER/M.KUKM/IX/2015 tentang Pelaksanaan Kegiatan Usaha Simpan Pinjam dan Pembiayaan Syariah. Regulasi ini memberikan legitimasi kepada LKMS untuk menjadikan koperasi sebagai badan hukumnya ${ }^{18}$.

yang sudah dilakukan sejak kecil maka lama kelamaan menjadi suatu kebiasaan untuk mematuhi kaedah-kaedah yang berlaku. (3) Utility, pada dasarnya manusia memiliki kecenderungan untuk hidup pantas dan teratur. (4) Group Indentification,yaitu seseorang akan mematuhi hukum ketika melihat atau mengacu pada kelompok yang telah melaksanakan. Lihat Soerjono Soekanto, Kesadaran Hukum dan Kepatuhan Hukum (Jakarta: CV Rajawali, 1982), h. 225-226.

16 Pada saat Undang-Undang ini mulai berlaku, Bank Desa, Lumbung Desa, Bank Pasar, Bank Pegawai, Badan Kredit Desa (BKD), Badan Kredit Kecamatan (BKK), Kredit Usaha Rakyat Kecil (KURK), Lembaga Perkreditan Kecamatan (LPK), Bank Karya Produksi Desa (BKPD), Badan Usaha Kredit Pedesaan (BUKP), Baitul Maal wa Tamwil (BMT), Baitul Tamwil Muhammadiyah (BTM), dan/atau lembaga-lembaga lainnya yang dipersamakan dengan itu tetap dapat beroperasi sampai dengan 1 (satu) tahun terhitung sejak Undang-Undang ini berlaku.

17 Lembaga-lembaga sebagaimana dimaksud pada ayat (1) wajib memperoleh izin usaha dari Otoritas Jasa Keuangan paling lama 1 (satu) tahun terhitung sejak Undang-Undang ini berlaku.

18 Pasal 1 ayat 2 Peraturan Menteri Koperasi dan Usaha Kecil dan Menengah Republik Indonesia Nomor 16 /Per/M.Kukm/Ix/2015 tentang Pelaksanaan Kegiatan Usaha Simpan Pinjam dan Pembiayaan Syariah oleh Koperasi. "Koperasi Simpan Pinjam dan Pembiayaan Syariah selanjutnya dalam peraturan ini disebut KSPPS adalah koperasi yang kegiatan usahanya meliputi simpanan, pinjaman dan pembiayaan sesuai prinsip syariah, termasuk mengelola zakat, infaq/sedekah, dan wakaf." 
Sehingga pengawasan dan pembinaan akan turut serta diberikan oleh dinas koperasi beserta jajarannya. Hal ini memperlihatkan adanya upaya saling klaim dalam memberikan legitimasi kepada LKMS yang berbadan hukum koperasi.

Kontradiksi aturan tersebut membuat LKMS yang berbadan hukum koperasi dihadapkan pada dua pilihan. Sebagaimana Koperasi LKMS Anggrek yang memilih mendaftar dan memperoleh izin usaha dari otoritas jasa keuangan sesuai amanat Undang-Undang Nomor 1 Tahun 2013 T entang Lembaga Keuangan Mikro $^{19}$. Langkah Koperasi LKMS Anggrek ini diperkuat dengan lontaran jawaban dari Ibu Sugiarti

Sebetulnya orang dinas koperasi ini sudah menyadari bahwa ini nanti semua lembaga keuangan bentuk apapun itu akan ada dibawah pengawasan otoritas jasa keuangan, sudah, sudah tau. Malah kadang-kadang piye yo, kayanya menakut-nakuti seperti ini, seperti ini, seperti ini, kenapa sih masuk ojk ? nanti susah lo, katanya gitu ${ }^{20}$.

Berat rasanya kehilangan aset berharga (nilai tambah) yang dapat meningkatkan citra positif suatu kinerja lembaga menjadi alasan bagi dinas koperasi. Hal ini merupakan alasan kuat keberatan dinas koperasi atas transformasi Koperasi Wanita Anggrek pada awalnya menjadi Koperasi LKMS Anggrek. Di samping itu, Koperasi Wanita Anggrek merupakan salah satu koperasi andalan yang dapat menunjukkan eksistensi dan sustainabilitasnya di tengah perkembangan perekonomian di Indonesia. Terbukti dengan peningkatan grafik kemajuan yang terus terjadi semenjak berdirinya lembaga ini. Ditambah dengan kinerja serius dan sungguh-sungguh para pengurus dalam mengoperasionalkannya. Kesungguhan kinerja ini tidak terlepas dari binaan dinas koperasi pada Koperasi Wanita Anggrek pada awalnya.

Namun, berbeda halnya dengan BTM Surya Umbulharjo. BTM Surya Umbulharjo tidak memiliki persepsi yang sama terkait Undang-Undang Nomor 1 Tahun 2013 tentang Lembaga Keuangan Mikro layaknya Koperasi LKMS Anggrek. Seperti lontaran jawaban Manajer BTM Surya Umbulharjo:

Polemik yang dirasakan teman-teman BMT dan BTM yaitu terkait sosialisasi diawal, antara Undang-Undang LKM dengan Undang-Undang Koperasi. Dan kami juga awalnya pernah disosialisasikan otoritas jasa keuangan, cuman kemudian ada tarik ulur jadi ada dua kepentingan, baik itu dari dinas koperasi

19 Pasal 9 Undang-Undang Nomor 1 Tahun 2013 Tentang Lembaga Keuangan Mikro "Sebelum menjalankan kegiatan usaha, Lembaga keuangan mikro harus memiliki izin usaha dari Otoritas Jasa Keuangan"

20 Sugiarti, Wawancara dengan Ketua Koperasi LKMS Anggrek Mojokerto, Kecamatan Kranggan, 18 Desember 2017. 
sendiri dan otoritas jasa keuangan. Kalau mendaftar pada otoritas jasa keuangan kan nanti ada dibawahnya kementrian keuangan ya, lah disana, maka kemudian kementrian koperasi mengambil langkah. karena mau tidak mau tidak semua koperasi dari BMT dan BTM itu kan dalam tanda kutip memiliki kemampuan yang tidak sama maka kementrian koperasi membuat kebijakan, maka muncullah izin usaha simpan pinjam syariah, biarpun sudah berbadan hukum sudah mengurus SIUP, TDP akan tetapi koperasi diwajibkan mengajukan surat izin usaha kepada dinas koperasi. Agar memiliki kekuatan hukum tersendiri. Dan berada pada pengawasan dinas koperasi ${ }^{21}$.

BTM Surya Umbulharjo masih berada di bawah pengawasan dan pembinaan dari dinas koperasi dan patuh terhadap Undang-Undang Nomor 25 Tahun 1992 tentang Perkoperasian beserta regulasi turunannya yaitu Peraturan Menteri Koperasi dan Usaha Kecil dan Menengah Republik Indonesia Nomor 16 /PER/M. KUKM/IX/2015 tentang Pelaksanaan Kegiatan Usaha Simpan Pinjam dan Pembiayaan Syariah. Sehingga amanat Undang-Undang Nomor 1 Tahun 2013 tentang Lembaga Keuangan Mikro dianggap tidak proporsional untuk operasional koperasi sesungguhnya bahkan sampai keluar dari ruh koperasi.

Selain dari perizinan usaha Undang-Undang Nomor 1 Tahun 2013 tentang Lembaga Keuangan Mikro juga mewajibkan adanya dewan pengawas syariah (DPS) bagi LKMS. Adapun mengenai proses penunjukan dewan pengawas syariah pada Koperasi LKMS Anggrek sebagaimana hasil paparan ketua Koperasi LKMS Anggrek

Dewan pengawas syariah yang kita miliki sekarang, ialah beliau yang sekarang juga menjabat sebagai dewan pengawas syariah BPRS Daerah Mojokerto, pak wali yang memilihkan. Beliau itu kan juga sebagai Ketua Majelis Ulama Kota Mojokerto atau apa gitu. Kan syaratnya mendaftarkan di otoritas jasa keuangan harus ada dewan pengawas syariah ya mas $^{22}$.

Pada pernyataan Ketua Koperasi LKMS Anggrek bahwasanya adanya regulasi yang mewajibkan suatu lembaga keuangan mikro yang menjalankan operasionalnya berbasis syariah, harus memiliki dewan pengawas syariah sebelum mendaftar pada otoritas jasa keuangan. Karena tidak dapat dipungkiri urgensi keberadaan dewan pengawas syariah dalam lembaga keuangan yang berbasis syariah sangat berguna untuk mengarahkan, membimbing serta mengawasi LKMS agar tidak keluar dari esensi syariah. Sehingga animo masyarakat muslim Indonesia untuk melakukan

21 Iwa Khairuttaqwa, Wawancara dengan Manajer BTM Surya Umbulharjo, Kecamatan Umbulharjo, 30 April 2018.

22 Sugiarti, Wawancara dengan Ketua Koperasi LKMS Anggrek Mojokerto. 
transaksi ekonomi dengan prinsip syariah tidak ternodai ataupun lepas kendali.

Selanjutnya, terkait skala cakupan wilayah, hal ini ditetapkan dengan jumlah modal awal yang dimiliki lembaga keuangan mikro tersebut ${ }^{23}$. Seperti pernyataan dari Ketua Koperasi LKMS Anggrek:

Pada saat kita mendaftarkan Koperasi Wanita Anggrek kepada otoritas jasa keuangan untuk menjadi koperasi LKMS Anggrek, modal yang kita tuangkan didalam Perubahan Anggaran Dasar (PAD) adalah sebesar Rp. 157.000.000, karena skala kita adalah kecamatan, tepatnya Kecamatan Kranggan ${ }^{24}$.

Paparan Ketua Koperasi LKMS Anggrek tersebut menunjukkan bahwa legalitas Koperasi LKMS Anggrek yang memiliki skala cakupan usaha setingkat kecamatan menjadi kokoh dan dapat dipertanggung jawabkan. Terakhir terkait pembinaan dan pengawasan, Undang-Undang Nomor 1 Tahun 2013 tentang Lembaga Keuangan Mikro mengamanatkan LKMS yang terdaftar dan mendapatkan ijin usaha, wajib memberikan laporan kepada otoritas jasa keuangan ${ }^{25}$. Hanya saja adanya perbedaan format pelaporan yang diberikan otoritas jasa keuangan dan dinas koperasi ${ }^{26}$. Begitu halnya dalam bidang pembinaan otoritas jasa keuangan tidak memberikan pembinaan secara langsung kepada LKMS yang telah terdaftar sehingga pembinaan dilimpahkan kepada pemerintah daerah ${ }^{27}$ yang terkait, padahal tidak semua pemerintah daerah memiliki tenaga ahli terkait LKMS. Hal ini dikarenakan otoritas jasa keuangan memiliki kewajiban pengawasan terhadap setiap lembaga yang melakukan mobilisasi dana di masyarakat.

23 Modal lembaga keuangan mikro terdiri dari modal disetor lembaga keuangan mikro yang berbadan hukum perseroan terbatas, atau simapanan pokok, simpanan wajib, dan hibah untuk lembaga keuangan mikro yang berbadan hukum koperasi. Paling kurang 50\% wajib digunakan untuk modal kerja dari modal yang disetorkan. Berikut jumlah besaran modal yang disetorkan, wilayah usaha kelurahan/desa : Rp. 50.000.000, wilayah usaha kecamatan : Rp. 100.000.000, wilayah usaha kabupaten/kota : Rp. 500.000 .000

24 Sugiarti, Wawancara dengan Ketua Koperasi LKMS Anggrek Mojokerto.

25 Pasal 28 ayat 1 Undang-Undang Nomor 1 Tahun 2013 Tentang Lembaga Keuangan Mikro "pembinaan, pengaturan dan pengawasan LKM dilakukan oleh otoritas jasa keuangan".

26 Contoh kecil pada pembiayaan macet, format laporan yang diinginkan otoritas jasa keuangan ialah dihapuskan dengan cara melakukan eksekusi kepada jaminan atau agunan anggota. Sedangkan format laporan yang diinginkan oleh dinas koperasi, hal itu tetap saja dilaporkan dengan judul piutang tak tertagih. Tentu hal ini tidak lepas karena kedekatan hubungan antara koperasi dengan anggotanya, proses eksekusi jaminan tidak dengan mudah dilakukan melainkan dengan bermusyawarah terlebih dahulu bersama anggotanya.

27 Pasal 28 ayat 3 Undang-Undang Nomor 1 Tahun 2013 Tentang Lembaga Keuangan Mikro, "Otoritas jasa keuangan dapat menunjuk pemerintah kota dalam melakukan pembinaan kepada lembaga keuangan mikro yang terdaftar pada otoritas jasa keuangan”. 
Sedangkan BTM Surya Umbulharjo yang belum terdaftar pada otoritas jasa keuangan hanya mendapatkan pembinaan dan pengawasan dari dinas koperasi, dikarenakan BTM Surya Umbulharjo berbadan hukum koperasi. Akan tetapi kegiatan usahanya masih dapat berjalan dengan baik, dan terus mendapat pembinaan dan pengawasan oleh dinas koperasi setempat. Sehingga ancaman sanksi didalam Undang-Undang Nomor 1 Tahun 2013 masih belum direalisasikan. Seperti pernyataan manajer BTM Surya Umbulharjo:

Fungsi dinas koperasi kan ada dua dalam bentuk pengawasan dan pembinaan, dalam bentuk pengawasan itu biasanya memberikan laporan keuangan triwulan, terkait masalah pembinaan dinas koperasi memberikan pelatihan-pelatihan, $\mathrm{SOP}, \mathrm{SOM}^{28}$.

Penyebab Kepatuhan dan Ketidakpatuhan LKMS yang Berbadan Hukum Koperasi terhadap Undang-Undang Nomor 1 Tahun 2013 tentang Lembaga Keuangan Mikro

Dualisme regulasi yang didapatkan oleh LKMS yang berbadan hukum koperasi, berimplikasi pada ujian bagi LKMS yang berbadan hukum koperasi apakah akan patuh dengan regulasi tersebut ataukah tidak. Kepatuhan LKMS yang berbadan hukum koperasi pada regulasi ini tentu saja didasari oleh berbagai kepentingan serta alasannya. Sampai saat ini data yang didapatkan penyusun dari website resmi otoritas jasa keuangan mengenai LKMS yang terdaftar pada otoritas jasa keuangan pertanggal 30 September 2017, hanya ada 17 LKMS yang berbadan hukum koperasi.

Koperasi LKMS Anggrek di Mojokerto, merupakan salah satu lembaga keuangan mikro syariah yang pertama kali patuh dengan regulasi Undang-Undang Nomor 1 Tahun 2013 tentang Lembaga Keuangan Mikro, dengan mendaftarkan diri pada otoritas jasa keuangan. Keputusan untuk mendaftarkan lembaga keuangan mikro pada otoritas jasa keuangan bukan hanya karena desakan ataupun ancaman sanksi ${ }^{29}$ yang akan diberikan pasca diterbitkannya Undang-Undang Nomor 1 Tahun 2013 tentang Lembaga Keuangan Mikro. Melainkan juga mengandung urgensi lainnya bagi masing-masing lembaga keuangan mikro.

28 Iwa Khairuttaqwa, Wawancara dengan Manajer BTM Surya Umbulharjo.

29 Pasal 34 ayat (1) Setiap orang yang menjalankan usaha LKM tanpa izin sebagaimana dimaksud dalam Pasal 9 ayat (1), Undang-Undang Nomor 1 Tahun 2013 tentang Lembaga Keuangan Mikro “dipidana dengan pidana penjara paling singkat 1 (satu) tahun dan paling lama 3 (tiga) tahun serta pidana denda paling sedikit Rp50.000.000,00 (lima puluh juta rupiah) dan paling banyak Rp1.000.000.000,00 (satu miliar rupiah). (2) Dalam hal kegiatan sebagaimana dimaksud pada ayat (1) dilakukan oleh badan hukum yang berbentuk perseroan terbatas atau koperasi, maka penuntutan terhadap badan-badan dimaksud dilakukan baik terhadap mereka yang member perintah melakukan perbuatan itu atau yang bertindak sebagai pimpinan dalam perbuatan itu atauterhadap kedua-duanya". 
Seperti halnya pada Koperasi LKMS Anggrek, kepatuhannya untuk mendaftar dan memperoleh ijin usaha dari otoritas jasa keuangan sekaligus ajang untuk ekspansi pangsa pasar dari koperasi tersebut. Hal ini tergambar jelas pada Koperasi LKMS Anggrek yang awalnya hanya melayani anggotanya yang bergender wanita dan terbatas pada lingkungan rukun tetangga (RT) setempat, karena statusnya sebagai Koperasi Wanita. Namun pasca transformasi menjadi Koperasi LKMS Anggrek, luas skala cakupan pangsa pasarnya sudah sampai satu kecamatan dan tidak terbatas pada anggota koperasi yang bergender wanita saja.

Kepatuhan Koperasi LKMS Anggrek terhadap Undang-Undang Nomor 1 Tahun 2013 tentang Lembaga Keuangan Mikro ketika dibenturkan dengan teori Kelman ${ }^{30}$ dalam membedakan kualitas ketaatan atau kepatuhan terhadap aturan, maka Koperasi LKMS Anggrek sudah mencapai kualitas kepatuhan yang bersifat identification, yaitu jika seseorang taat terhadap suatu aturan dikarenakan takut hubungan baiknya dengan seseorang rusak. Seperti halnya yang disampaikan oleh ketua LKMS Anggrek

Bapak wali kan kiai jadi beliau ingin diadakan juga LKMS yang maju untuk mendampingi kemajuan BPRS Daerah Mojokerto. Masalah Dewan Pengawas Syariah pun, kan pak wali yang mencarikan, dan ada beberapa urusan dalam persiapan perubahan menjadi Koperasi LKMS Anggrek, dan mendaftarkan di otoritas jasa keuangan, juga diurus sama pemerintah kota. Sebenarnya saya ini ngga apa, mau diapan saja saya ngga papa, saya ini wayang, mau diapakan saja monggo. Hehehe, karena ini juga bukan modal saya, tapi tujuan kita juga mensukseskan program pak wali ${ }^{31}$.

Senafas pula dengan komitmen normatif melalui legitimasi (normative commitment through legitimacy) yang berarti patuh pada peraturan karena otoritas penyusun hukum yang memiliki hak untuk mendikte perilaku juga dirasakan oleh Koperasi LKMS Anggrek. Faktanya perkembangan Koperasi LKMS Anggrek tidak lepas dari bantuan dana hibah dari Gubernur dan Pemerintah Kota. Sehingga tidak dapat dipungkiri campur tangan penguasa masih dapat dirasakan.

Kebermaksudan (maqasid) Koperasi LKMS Anggrek dalam mematuhi Undang-Undang Nomor 1 Tahun 2013 tentang Lembaga Keuangan Mikro dapat

30 Ketaatan atau kepatuhan subyek hukum terhadap aturan, terbagi kedalam tiga yaitu :

(1) Ketaatan yang bersifat compliance diartikan sebagai suatu kepatuhan yang didasarkan kepada harapan akan suatu imbalan. (2) Ketaatan yang bersifat identification, terjadi apabila kepatuhan terhadap kaedah hukum ada bukan karena nilai intrinsiknya, akan tetapi agar keanggotaan kelompok tetap terjaga serta ada hubungan baik dengan mereka yang diberi wewenang untuk menerapkan kaedah-kaedah hukum tersebut. (3) Ketaatan yang bersifat internalisation, lihat Soekanto, KesadaranHukum dan Kepatuhan Hukum, h. 230-231.

31 Sugiarti, Wawancara dengan Ketua Koperasi LKMS Anggrek Mojokerto. 
dipandang dari dua sisi. Sisi pertama mengandung maksud perkembangan ekonomi, agar Koperasi LKMS Anggrek dapat memperluas skala cakupan wilayahnya menjadi satu kecamatan ( hifz al-mal). Agar harta yang telah terhimpun tidak stagnan, akan tetapi dilakukan pengelolaan yang terstruktur dengan mengedepankan prinsip kehati-hatian dan tanggung jawab sehingga hartanya berkembang dan terjaga. Karena keputusan para pengurus Koperasi LKMS Anggrek membentuk lembaga keuangan merupakan gerbang awal penghimpunan dana dari anggotanya dalam bentuk simpanan, yang akan diolah dan dioperasionalkan. Para anggotapun telah memberikan kepercayaan penuh kepada Pengurus Koperasi LKMS Anggrek dalam mentasyarufkan kekayaan atau hartanya.

Sisi kedua mengandung maksud hubungan sosial, agar hubungan baik dengan Walikota Mojokerto tetap terjalin dan sebagai upaya pensuksesan program kerja Walikota Mojokerto dalam mewujudkan "Service City" (bifzan-nafs). Selain itu, penjagaan dan pemeliharaan jiwa yang dimaksud ialah menjalin keutuhan silaturrahmi dengan Wali Kota Mojokerto dalam upaya pencapaian suatu tujuan untuk mensejahterakan serta membantu masyarakat yang berada dalam skala ekonomi mikro dilingkungan Mojokerto lebih luas lagi.

Sedangkan, ketidakpatuhan LKMS untuk mengimplementasikan regulasi tersebut dimulai dari keengganan lembaga keuangan mikro mendapatkan izin usaha dari otoritas jasa keuangan. Keengganan tersebut beralasan, karena apabila LKMS melakukan kegiatan usaha melebihi satu wilayah kabupaten/kota tempat kedudukan lembaga keuangan mikro tersebut, maka akan menimbulkan implikasi wajibnya bertransformasi menjadi Bank Pengkreditan Rakyat atau Bank Pembiayaan Rakyat Syariah. ${ }^{32}$ Padahal konsep awal dari pendirian ataupun pembentukan LKMS yang berbadan hukum koperasi didasarkan atas tujuan untuk meningkatkan pendapatan dan mensejahterakan anggotanya atau masyarakat sekitar secara bersama-sama sehingga sudah sangat berbeda dengan tujuan Bank Pengkreditan Rakyat atau Bank Pembiayaan Rakyat Syariah. Terlebih lagi LKMS banyak memulai operasionalnya di lingkungan pondok pesantren. Peran seorang kiai yang mengomandaninya menjadi langkah awal dalam menerapkan operasional yang berbasis syariah. Dikarenakan adanya sifat $z u b u d^{33}$, yang tidak hanya mencari

32 Pasal 27 Undang-Undang Nomor 1 Tahun 2013 tentang Lembaga Keuangan Mikro"LKM wajib bertransformasi menjadi bank jika: (a) LKM melakukan kegiatan usaha melebihi 1 wilayah kabupaten/kota tempat kedudukan LKM atau (b) LKM telah memenuhi persyaratan yang ditetapkan dalam Peraturan Otoritas Jasa Keuangan".

33 Zuhud adalah suatu sikap hidup di mana seseorang tidak mementingkan harta kekayaan atau dunia. Harta kekayaan dan dunia hanyalah sarana untuk mencapai tujuan hakiki yakni kehidupan akhirat. Zuhud kepada dunia bukanlah mengharamkan yang halal dan membuang semua harta, serta tidak mau menikmati hal-hal yang bersifat duniawi, tetapi lebih meyakini apa yang ada di 
profit orientied membuat nilai sosial yang diusung LKMS dapat tercapai. Bahkan sampai pada keilmuan fiqh muamalat yang dimilikinya agar sistem syariah yang diterapkan tidak ternodai. ${ }^{34}$

Apabila dikembalikan kepada definisi lembaga keuangan mikro yang merupakan lembaga keuangan yang khusus didirikan untuk memberikan jasa pengembangan usaha dan pemberdayaan masyarakat baik melalui pinjaman atau pembiayaan dalam skala usaha mikro kepada anggota dan masyarakat, pengelolaan simpanan, maupun pemberian jasa konsultasi pengembangan usaha yang tidak semata-mata mencari keuntungan. Maka terlihat jelas bahwasanya tidak hanya keuntungan (profit) yang menjadi tujuan awal pembentukan LKMS, Akan tetapi jauh sampai pada pelayanan sosial antar masyarakat yang berskala usaha mikro.

Selain itu, juga pengawasan dan pembinaan yang diberikan otoritas jasa keuangan dianggap tidak mengandung kepastian hukum, karena otoritas jasa keuangan dan juga kementrian koperasi memang memiliki jalurnya masingmasing. Kendatipun pembinaan selanjutnya diserahkan kepada dinas koperasi dan perangkatnya. Ditambah lagi perilaku oportunis, yang memungkinkan LKMS tersebut bisa mendapatkan keuntungan yang lebih besar baik materil maupun immateril ketika tidak mengimplementasikan Undang-Undang Nomor 1 Tahun 2013 tentang Lembaga Keuangan Mikro.

Kesadaran BTM Surya Umbulharjo akan Undang-Undang Nomor 1 Tahun 2013 tentang Lembaga Keuangan Mikro sudah terbentuk sejak regulasi ini diundangkan. Hanya saja adanya anggapan terkait aturan dalam Undang-Undang Nomor 1 Tahun 2013 tentang Lembaga Keuangan Mikro menghilangkan ruh dan ghiroh koperasi. Regulasi ini terkesan lebih mengarah untuk menyentil lembaga keuangan mikro yang berbadan hukum koperasi yang nakal, yaitu mereka yang menerapkan operasionalnya layaknya perbankan. Maka dari kesadaran ini tidak serta merta mengantarkan pada kepatuhan terhadap Undang-Undang Nomor 1 Tahun 2013 tentang Lembaga Keuangan Mikro.

Namun langkah para pengurus dalam mengelola harta yang telah terhimpun dengan cara pengelolaan yang terstruktur, mengedepankan prinsip kehati-hatian dan tanggung jawab menyebabkan hartanya berkembang dan terjaga, merupakan upaya pemeliharaan harta anggotanya ( $h i f z$ al-mal). Sedangkan jalinan hubungan

sisi Allah ketimbang apa yang ada di tangan kita. Lihat M. Yatimin Abdullah, Studi Akhlak dalam Perspektif (Jakarta: Amzah, 2007), h. 53

34 Peran dan fungsi koperasi berbasis konvensional lebih mengutamakan mencari keuntungan untuk kesejahteraan anggota, baik secara tunai atau membungakan uang yang ada pada anggota. Sedangkan konsep koperasi yang berbasis syariah mengharuskan memberikan pelayanan sosial baik kepada anggota yang membutuhkan maupun masyarakat dhu'afa. LihatNur S. Buchori, Koperasi Syariah (Banten: Pustaka Aufa Media, 2012), h. 13-15. 
baik dengan dinas koperasi selaku lembaga pengawas diatasnya merupakan interprestasi dari upaya ( $h i f z$ an-nafs). Maka nampak terlihat pengaplikasian pasal 39 dalam Undang-Undang Nomor 1 Tahun 2013 tentang Lembaga Keuangan Mikro belum berjalan dengan baik.

Akhirnya kepatuhan LKMS yang berbadan hukum koperasi dan mendaftar pada Otoritas Jasa Keuangan terhadap regulasi ini tidak sepenuhnya menjadi penghambat untuk beroperasi. Koperasi menjadi pilihan badan hukum yang lebih digemari. Pendampingan dan pembinaan dari Kementerian Koperasi dan perangkatnya maupun Otoritas Jasa Keuangan menjadi harapan yang dinanti. Namun tambahan pelaporan kepada Otoritas Jasa Keuangan juga tetap harus ditaati. Hal ini berguna untuk melihat perkembangan dan operasionalnya agar tetap terkendali. Sehingga tingkat good corporate governance ${ }^{35}$ (kesehatan instansi) yang meningkat menjadi bukti. Agar anggota dan nasabah tertarik dan yakin untuk berpartisipasi.

\section{Simpulan}

Kekuatan hukum untuk mengikat lembaga keuangan mikro sesuai amanat pasal 39 Undang-Undang Nomor 1 Tahun 2013 tentang Lembaga Keuangan Mikro membuat Koperasi LKMS Anggrek mendaftar pada Otoritas Jasa Keuangan dengan melakukan perubahan anggaran dasar (PAD) yang bertujuan untuk merubah dan menambah beberapa poin yang masih belum sesuai, terkait kelembagaan, kegiatan usaha dan cakupannya, serta pembinaan dan pengawasan. Sedangkan BTM Surya Umbulharjo tidak demikian, melainkan lebih memilih PERMEN Nomor 16 /PER/M.KUKM/IX/2015 tentang Pelaksanaan KSPPS untuk memayungi operasionalnya, sesuai dengan arahan dinas koperasi. Hal ini dikarenakan, adanya polemik terkait Undang-Undang Nomor 1 Tahun 2013 tentang Lembaga Keuangan Mikro dengan Undang-Undang Nomor 25 Tahun 1992 tentang Perkoperasian beserta aturan turunan.

Kepatuhan Koperasi LKMS Anggrek untuk mendaftar pada otoritas jasa keuangan agar mendapatkan izin usaha, tentu saja tidak lepas dari komitmen normatif melalui legitimasiyaitu adanya kesadaran bahwa pembuat hukum memiliki otoritas untuk mendikte.Ketika diukur dalam tingkat kepatuhan, maka kepatuhan

35 Good corporate governance merupakan cara mengatur suatu hubungan internal dan eksternal perusahaan dan pengendalian perusahaan dengan baik, yaitu penata kelolaan perusahaan yang sehat lagi baik dengan berdasarkan prinsip transparency, accountability, responsibility, independe ncy, dan fairness. LihatRatieh Widiastuti, Ahmad Nurkhin, Murdian Susilowati, "Peran Financial Performance dan Memediasi Pengaruh Good Corporate Governance Terhadap Financial Distress," Jurnal Economia 15 (April 2019): 34-47. 
Koperasi LKMS Anggrek sampai pada tahap identification, yaitu taat terhadap suatu aturan karena takut merusak hubungan baiknya dengan Walikota dan upaya mewujudkan program "Service City" (hifz an-nafs) dan mengandung maksud perkembangan ekonomi, agar Koperasi LKMS Anggrek dapat memperluas skala cakupan wilayahnya menjadi satu kecamatan ( $h i f z$ al-mal). Sedangkan kesadaran hukum BTM Surya Umbulharjo terhadap Undang-Undang Nomor 1 Tahun 2013 tentang Lembaga Keuangan Mikro, tidak serta merta mengantarkan BTM Surya Umbulharjo kepada kepatuhan, dikarenakan Undang-Undang tersebut keluar dan menghilangkan ruh koperasi. Namun langkah pengurus dalam mengelola harta merupakan upaya ( $h i f z a l-m a l)$. Sedangkan jalinan hubungan baik dengan dinas koperasi selaku lembaga pengawas diatasnya merupakan interprestasi dari upaya (hifz an-nafs).

\section{Daftar Pustaka}

Abdullah, M. Yatimin. Studi Akblak dalam Perspektif. Jakarta: Amzah, 2007.

Fadillah Mursid. Kebijakan Regulasi Baitul Maal Wat Tamwil (BMT) di Indonesia. Tesis, UIN Sunan Kalijaga, 2017.

Hakim, Lukman. Methodologi Penelitian. Surakarta: UMS Press, 2004.

Hasan, Iqbal. Methode Penelitian dan Aplikasinya. Jakarta: Ghalia Indonesia, 2002. Imaniyati, Neni Sri. Aspek-Aspek Hukum BMT (Baitul Maal Wat Tamwil). Bandung: Citra Aditya Bakti, 2010.

Mokh Syaiful Bakhri. BMT UGT Sidogiri Urutan 4 (empat) Koperasi Besar Indonesia, 17 Januari 2018. http://bmtugtsidogiri.co.id/baru/berita-505. html.

Muhammad Kamal Zubair. Sustainabilitas Lembaga Keuangan Mikro Syariah. Disertasi, UIN Sunan Kalijaga, 2016.

Nely Merina. Jumlah Koperasi Syariah di Indonesia Mencapai 150.223, 17 Januari 2018. https://www.google.com/amp/goukm.id/jumlah-koperasi-syariah-di indonesia mencapai-150-223/amp/.

Nur S. Buchori. Koperasi Syariah. Banten: Pustaka Aufa Media, 2012.

OJK. “Data Lembaga Keuangan Mikro Yang Terdaftar Di Ojk Per 30 September 2017," 30 Januari 2018. http://www.ojk.go.id. 
Soekanto, Soerjono. Kesadaran Hukum dan Kepatuhan Hukum. Jakarta: CV Rajawali, 1982

\section{Artikel}

Muhammad Muhtarom. Reformulasi Peraturan Hukum Lembaga Keuangan Mikro Syariah Di Indonesia. PROFETIKA, Jurnal Studi Islam 17 (Juni 2016): 90-102.

Marullah, Izza. Membumikan Konsep Syariah Dalam Ekonomi Berbasis

Kerakyatan (Baitul Maal wat Tamwil Sebagai sebuah Solusi).Jurnal Ekonomi Pembangunan, 2002, 195-205.

Nourma Dewi. Regulasi Keberadaan Baitul Maal Wat Tamwil (BMT) Dalam Sistem Perekonomian Di Indonesia.Jurnal Serambi Hukum 01 (Juni 2017): 96-110.

Novita Dewi Masyitoh. Analisis Normatif Undang-Undang No 1 Tahun 2013 tentang Lembaga Keuangan Mikro (LKM) Atas Status Badan Hukum Dan Pengawasan Baitul Maal Wat Tamwil (BMT). CONOMICA: Jurnal Pemikiran dan Penelitian Ekonomi Islam V (Oktober 2014): 17-36.

Ratieh Widiastuti, Ahmad Nurkhin, Murdian Susilowati. "Peran Financial Performance dan Memediasi Pengaruh Good Corporate Governance Terhadap Financial Distress." Jurnal Economia 15 (April 2019): 34-47. 